\title{
Tubulovillous adenoma of the duodenal papilla: radiological-endoscopic and anatomopathological correlation in the surgical proposal
}

\author{
(D) Daniel Alvarenga Fernandes ${ }^{1}$ \\ (iD) Yuri Longatto Boteon $n^{2,3}$ \\ Amanda Pinter Carvalheiro da Silva Boteon ${ }^{2}$ \\ (iD) Rachid Marwan Pinheiro Sousa ${ }^{1}$ \\ (DD) Daniel Lahan Martins ${ }^{1}$ \\ (D) Thiago José Penachim ${ }^{1}$ \\ Dicardo Hoelz de Oliveira Barros ${ }^{1}$ \\ (iD) Rita de Cássia Perina Martins ${ }^{4}$ \\ (iD) Larissa Bastos Eloy da Costa \\ (iD) Everton Cazzo ${ }^{5}$ \\ (iD) Martinho Antônio Gestic ${ }^{5}$ \\ (DD) Elinton Adami Chaim ${ }^{5}$ \\ Delson Marcio Gomes Caserta ${ }^{1}$
}

\begin{abstract}
1. Departamento de Radiologia, Faculdade de Ciências Médicas da Universidade Estadual de Campinas (FCM- Unicamp), Campinas, SP, Brasil. 2. University Hospitals Birmingham NHS Foundation Trust, Queen Elizabeth Hospital Birmingham, Birmingham, United Kingdom. 3. Centre for Liver and Gastrointestinal Research, Institute for Immunology and Immunotherapy, University of Birmingham, Birmingham, United Kingdom. 4. Departamento de Anatomia Patológica, Faculdade de Ciências Médicas da Universidade Estadual de Campinas (FCM- Unicamp), Campinas, SP, Brasil. 5. Departamento de Cirurgia, Faculdade de Ciências Médicas da Universidade Estadual de Campinas (FCM- Unicamp), Campinas, SP, Brasil.
\end{abstract}

\section{SUMMARY}

Tubulovillous adenomas of the duodenal ampulla are rare neoplasms. The present report describes a case with radiological-endoscopic and pathological correlation in which the patient underwent duodenal pancreatectomy with good postoperative progression. With advanced imaging methods, especially magnetic resonance and endoscopic ultrasound, locoregional aspects and extraluminal, lymphovascular, and metastatic invasion have been increasingly discussed as contributors to therapeutic decision making. This progression improves lesion staging and is especially useful in selecting eligible candidates for endoscopic treatment.

KEYWORDS: Intestinal neoplasms; Adenoma; Villous Adenoma; Diagnostic Imaging; Magnetic Resonance Imaging

\section{INTRODUCTION}

Tubulovillous adenomas account for approximately $1 \%$ of all duodenal tumors ${ }^{1-3}$. Most of them are initially asymptomatic. Fluctuating jaundice and biliary colic may progressively appear with the growth of these tumors. Less frequently, pancreatitis and upper gastrointestinal bleeding have been reported ${ }^{1-3}$. In addition to diagnosis, complementary imaging tests with increasingly improved resolution can improve individualized surgical planning and discussion. 


\section{CLINICAL CASE}

A 61-year-old white female patient who was born in São Paulo, Brasil had a body mass index of $21 \mathrm{~kg} /$ $\mathrm{m}^{2}$ and grade I hypertension that was well controlled with medications. She had no other comorbidities or pathological history. The patient reported pain in the right hypochondrium accompanied by 10-kg weight loss, vomiting, fluctuating jaundice, and intermittent fever $\left(38.5^{\circ} \mathrm{C}\right)$ for approximately 6 months. On physical examination, she exhibited regular general condition, jaundice $(2+/ 4+)$, and pain on deep palpation in the right hypochondrium. Other organs did not exhibit significant changes. Laboratory tests showed hyperbilirubinemia at the expense of direct bilirubin (4.4 mg/dL).

Abdominal ultrasound (US) showed cholecystolithiasis with a solid mass close to the distal bile duct. The size of the mass was $5.5 \mathrm{~cm}$ in the longest axis.
It exhibited inside flow on Doppler study and intrahepatic and extrahepatic bile duct dilation (Figures $1 \mathrm{~A}$ and $1 \mathrm{~B})$. Diagnostic investigations included multislice computed tomography (CT) (Figures 1C and 1D), magnetic resonance imaging (MRI), and magnetic resonance cholangiopancreatography (MRCP) (Figures $2 \mathrm{~A}, 2 \mathrm{~B}$, and $2 \mathrm{C}$ ). Imaging examinations revealed a swirl-patterned solid mass in the duodenal papillary topography (called the "intraduodenal cerebellum" sign by the authors due to the swirl pattern of the tumor surface). The mass was $5.5 \mathrm{~cm} \times 4.0$ $\mathrm{cm} \times 2.5 \mathrm{~cm}$ in size and associated with intrahepatic and extrahepatic bile duct dilation up to the mass plane with no evidence of lymphovascular or metastatic involvement.

Upper digestive endoscopy with biopsy and endoscopic retrograde cholangiopancreatography (ERCP) showed a multilobulated polypoid lesion sized 5-6 cm

FIGURE 1. ABDOMINAL ULTRASOUND SHOWED A SOLID MASS CLOSE TO THE DISTAL BILE DUCT. IT EXHIBITED INSIDE FLOW ON DOPPLER STUDY (A, UPPER LEFT) AND INTRAHEPATIC AND EXTRAHEPATIC BILE DUCT DILATION (B, UPPER RIGHT). AXIAL (C, LOWER LEFT) AND CORONAL (D, LOWER RIGHT) COMPUTED TOMOGRAPHY SECTIONS SHOW CHOLECYSTOLITHIASIS (BLACK ARROW) AND A SOLID MASS IN THE DUODENAL PAPILLARY TOPOGRAPHY (WHITE ARROWS). THE MASS WAS $5.5 \mathrm{CM} \times 4.0 \mathrm{CM} \times 2.5 \mathrm{CM}$ IN SIZE, WITH MODERATE AND HOMOGENEOUS IMPREGNATION AFTER CONTRAST AND A SWIRL SURFACE PATTERN (CALLED "INTRADUODENAL CEREBELLUM" SIGN BY THE AUTHORS DUE TO THE SWIRL PATTERN OF THE TUMOR SURFACE).

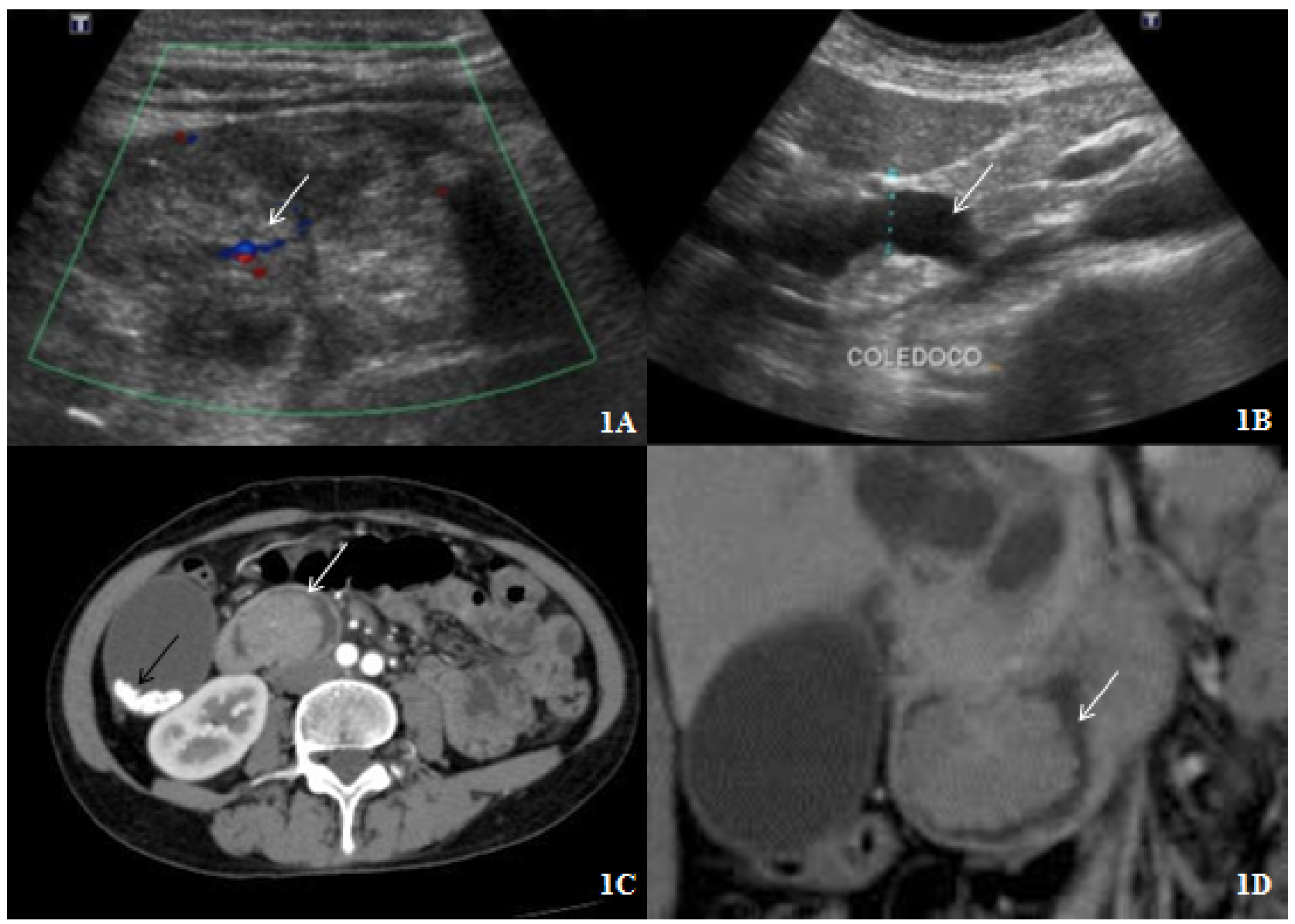


in the region of the papilla of Vater. Histopathological analysis (Figure 2D) showed a tubular adenoma with high-grade intraepithelial neoplasia of the duodenal papilla. Considering a suspected malignant transformation and the extent of the lesion, duodenal pancreatectomy was selected in the present case. Histopathological diagnosis of the surgical specimen was tubulovillous adenoma of the papilla of Vater with superficial foci of well-differentiated adenocarcinoma and duodenal surgical margins (proximal and distal). Distal pancreas and the bile duct were free of neoplasia, with no lymph node involvement or vascular invasion (stage I) (Figures 3A, 3B, 3C, 3D). Chronic calculous cholecystitis was also present with extensive pseudo-pyloric metaplasia. The patient exhibited good postoperative progression. She was discharged in good general condition and is still under outpatient follow-up.

FIGURE 2. CORONAL SECTION OF T1-WEIGHTED MAGNETIC RESONANCE IMAGE AFTER CONTRAST SHOWS HOMOGENEOUS MASS IMPREGNATION IN THE DUODENAL PAPILLARY TOPOGRAPHY IN ADDITION TO CHOLECYSTOLITHIASIS (A, UPPER LEFT). DIFFUSION-WEIGHTED IMAGES WITH A B-VALUE OF 1,000 SHOW RESTRICTION OF WATER MOLECULE DIFFUSION BY THE MASS (B, UPPER RIGHT). MAGNETIC RESONANCE CHOLANGIOPANCREATOGRAPHY (C, LOWER LEFT) SHOWS INTRAHEPATIC AND EXTRAHEPATIC BILE DUCT DILATION UP TO THE MASS PLANE IN THE DUODENAL PAPILLARY TOPOGRAPHY. UPPER DIGESTIVE ENDOSCOPY (D, LOWER RIGHT) SHOWS A LESION IN THE POST-BULBAR REGION IN THE DUODENAL PAPILLARY TOPOGRAPHY, WITH A LOBULATED AND WHITISH SURFACE, DEFINED LIMITS, AND A VESSEL IN ITS CENTER ASSOCIATED WITH ADJACENT WHITISH MUCOUS LINING.

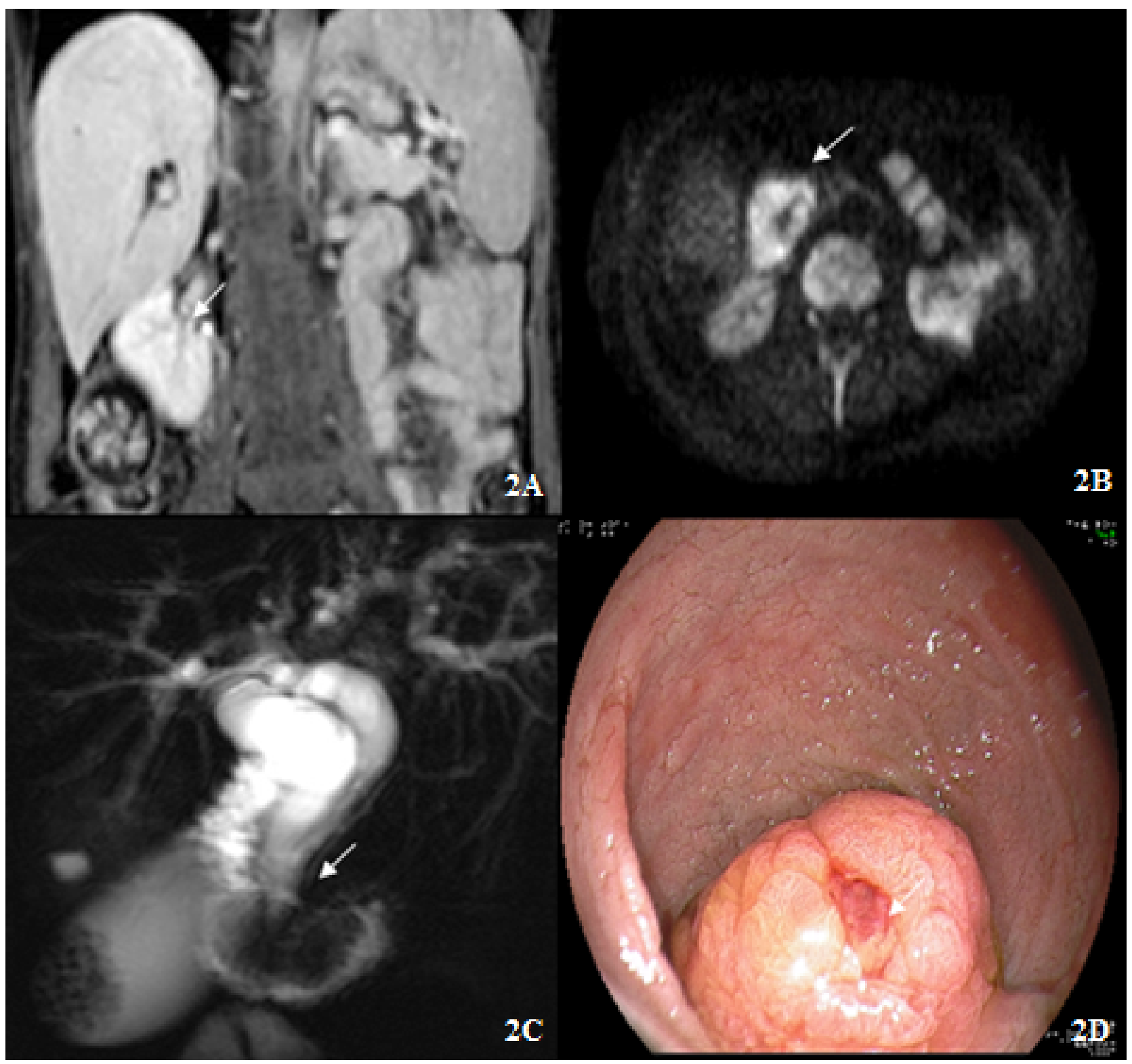


FIGURE 3. MACROSCOPICALLY, SURGICAL SPECIMEN (A) SHOWS A POLYPOID LESION MEASURING 5.5 CM × 4.0 CM $\times 2.5 \mathrm{CM}$, WITH IRREGULAR SURFACE, VILLOUS APPEARANCE, AND FRIABLE CONSISTENCY. MACROSCOPIC ANATOMOPATHOLOGICAL EVALUATION (B) SHOWS THE TRANSVERSE SECTION OF THE LESION AT THE LEVEL OF THE BILE DUCT (ARROW), SHOWING A CEREBELLAR PRESENTATION WITH A SWIRL PATTERN SIMILAR TO THAT OBSERVED IN THE RADIOLOGICAL IMAGES. MICROSCOPIC EXAMINATION (C) SHOWS VILLOUS STRUCTURES LINED BY COLUMNAR EPITHELIUM WITH PALISADED ARRANGEMENT OF NUCLEI (HEMATOXYLIN AND EOSIN, 100×). SUPERFICIAL ADENOCARCINOMATOUS FOCI WITH ATYPICAL NUCLEI FORMING GLANDULAR STRUCTURES (D) ARE OBSERVED (HEMATOXYLIN AND EOSIN, 400×).

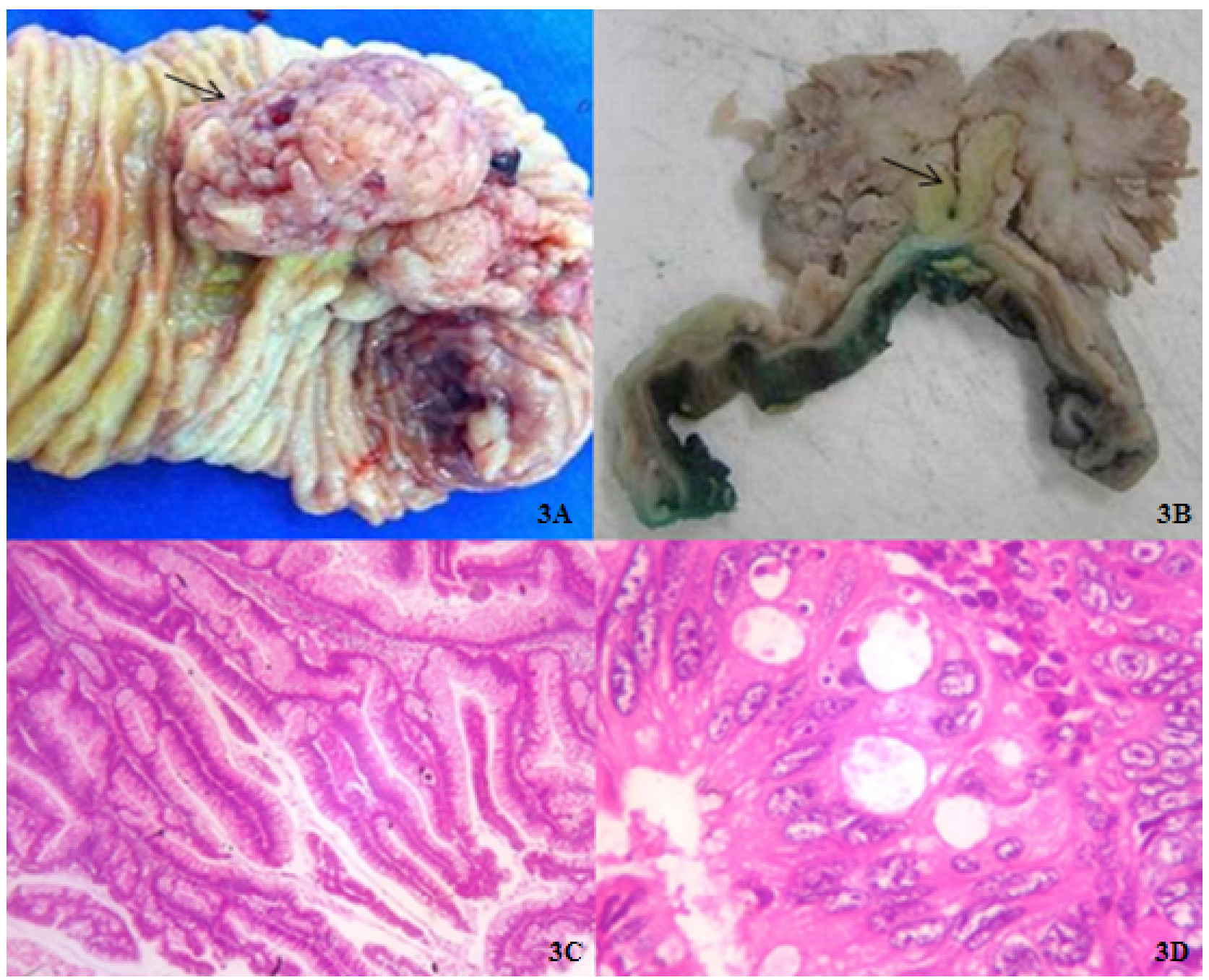

\section{DISCUSSION}

The major duodenal papilla or the ampulla of Vater is a small nipple-like elevation located on the posteromedial wall of the descending part of the duodenum. It is formed by the union of intramural portions of the bile duct and the main pancreatic duct. Periampullary tumors are present at approximately up to $2.0 \mathrm{~cm}$ from the duodenal papilla. The four most common types are tumors of the cephalic portion and the uncinate process of the pancreas (50-70\%), tumors of the duodenal ampulla, tumors of the duodenum, and tumors of the distal bile duct ${ }^{1-}$ ${ }^{3}$. The complex anatomy of the periampullary region, which is closely related to the pancreas and the biliary tract, is associated with difficulties in diagnostic accuracy and in staging via imaging examinations. Recent emphasis on MRI and endoscopic ultrasound (EUS) has improved the controversial management of these tumors and underlined the need for multidisciplinary treatment ${ }^{1-3}$.

Benign neoplasms of the ampulla of Vater are premalignant and rare lesions, with very few cases reported in the literature ${ }^{1-3}$. Currently, these lesions are being diagnosed with greater frequency due to greater availability of imaging methods such as US, CT, EUS and due to improved patient screening and follow-up in the presence of risk factors. Ampullary adenomas are sporadic or associated with familial polypoid syndromes such as familial adenomatous 
polyposis $^{4-6}$. Adenomas are more common in the colon and are rarely observed in the small intestine. Duodenal tubulovillous adenoma was first described by Perry in 1893 and was called duodenal papilloma. Duodenal tubulovillous adenomas are very uncommon, accounting for approximately $1 \%$ of all duodenal tumors ${ }^{4-6}$. Most of the duodenal tumors are present in the descending part of the duodenum and in the periampullary region. The onset of this lesion is mainly between the fifth and the seventh decade of life and the prevalence is similar between sexes ${ }^{5-7}$. These tumors are named according to staging and morphology as villous adenomas, papillary adenomas, villous papillomas, tubulovillous adenomas, or villous glandular polyps ${ }^{8}$.

Considering the presence of malignancy in approximately $30 \%$ to $40 \%$ of the tubulovillous adenomas (similar to the adenoma-adenocarcinoma sequence in colorectal tumors) and the size (larger tumors generally have a greater chance of malignancy), histological type (villous: carcinomas are more frequent), location (ampullary lesions are more likely to contain carcinomatous foci than duodenal or small intestine lesions), number (multicentric tumors have a higher rate of malignancy), and recurrence rate; the surgical approach involves local resection (endoscopic resection, ampullary resection, or duodenotomy) and follow-up or duodenal pancreatectomy. However, the selection of treatment approach is still controversial ${ }^{9-11}$. Duodenal pancreatectomy was selected in the present case due to the suspected malignant transformation and the extent of the lesion.

Propaedeutic imaging methods such as US, CT, MRCP, ERCP, EUS, and intraductal US improve the diagnosis and surgical management. Imaging examinations are important in surgical planning to evaluate the extraluminal extent of invasive tumors, lymphovascular involvement, and the presence of metastases. In the absence of lymphovascular involvement and metastases, locoregional aspects have been discussed as contributors to therapeutic decision making. Advanced staging methods are especially useful tools to select eligible patients for endoscopic treatment ${ }^{12-14}$.

The tomographic appearance of duodenal tubulovillous adenoma is not specific, with attenuation and varying degrees of contrast impregnation. However, larger tumors may present a swirl surface pattern similar to the one observed in the present case, which resembles the image and the macroscopic aspect of the cerebellum (called "intraduodenal cerebellum" sign by the authors due to the swirl pattern of the tumor surface). This presentation may be caused by villous projections and friable tumor pattern on imaging and macroscopic examination. Knowledge about the tumor appearance may help define a suspected imaging diagnosis ${ }^{4,15,16}$. Imaging differentials allow the inclusion of pseudo-tumors (tumors that can simulate a polypoid mass on CT, but have the same imaging characteristics as the rest of the duodenal mucosa), non-neoplastic hyperplasia of duodenal submucosal glands (Brunner's glands), other duodenal polyps such as epithelial (mucosal lesions) and intramural polyps (submucosal lesions such as stromal tumor of gastrointestinal origin and other mesenchymal tumors), duodenal carcinoma, ampullary carcinoma, metastases, and lymphoma ${ }^{15,16}$. Another advantage of CT is the possibility of local staging of any vascular invasion in cases of more aggressive lesions.

Recently, an algorithm was suggested to manage ampullary adenoma diagnosed at biopsy ${ }^{12,14}$. EUS/CT were suggested for staging in the presence of one of the following characteristics: tumors larger than 1 $\mathrm{cm}$, high degree of dysplasia, ulceration, irregular margins, and spontaneous bleeding or friable consistency on endoscopic examination. In the absence of any of the aforementioned characteristics, management options include endoscopic resection and surveillance. Patients undergoing local surgical or endoscopic resection require prolonged follow-up with imaging examinations. Treatment options in EUS/CT staging with invasive characteristics such as lymphovascular invasion, intraductal growth, and metastases include surgical approach/ablative therapy ${ }^{12,14}$. EUS can accurately predict the depth of mucosal invasion in the preoperative evaluation of periampullary and duodenal adenomas, making it possible to consider endoscopic therapy or local resection in selected patients, avoiding more extensive surgery ${ }^{14}$.

MRI has shown a good correlation with histopathological findings in the evaluation of peritumoral invasion of adjacent periampullary tissues, with significant sensitivity (88\%), specificity (100\%), accuracy (96\%), positive predictive value (100\%), and negative predictive value $(94 \%)^{4}$. Although it has lower spatial resolution compared to $\mathrm{CT}$, the high anatomical resolution of MRI can identify signal changes in 
structural disorders of the periampullary region, pancreatic cephalic portion, main pancreatic duct walls, and the common bile duct ${ }^{4}$. An associated MRCP allows a noninvasive panoramic evaluation of the biliary and pancreatic pathways through heavily T2-weighted images. Good locoregional evaluation of periampullary tumors can improve surgical planning and management.

\section{CONCLUSION}

Tubulovillous adenomas of the duodenal papilla are rare neoplasms that are being diagnosed with greater frequency. Multidisciplinary approach and recent imaging advances with emphasis on EUS and high tissue resolution of MRI have allowed discussions regarding new surgical approaches such as endoscopic therapy in selected cases.

\section{RESUMO}

Os adenomas túbulo-vilosos da ampola duodenal são neoplasias raras. Neste trabalho apresentamos um caso com correlação radiológico-endoscópica e patológica, tendo a paciente sido submetida à duodenopancreatectomia com boa evolução pós-operatória. Com os avanços dos métodos de imagem, em especial da ressonância magnética e ultrassonografia endoscópica, aspectos locorregionais, além da invasão extraluminal, linfovascular e metastática, têm sido discutidos de maneira crescente como contribuintes na decisão terapêutica. Essa evolução contribui para o melhor estadiamento destas lesões e é especialmente útil para selecionar candidatos elegiveis ao tratamento endoscópico.

PALAVRAS-CHAVE: Neoplasias Intestinais; Adenoma; Adenoma Viloso; Diagnóstico por Imagem; Imagem por Ressonância Magnética.

\section{REFERENCES}

1. In SG, Chen ZY, Yan LN, Zeng Y, Huang W, Xu N. A rare case of periampullary carcinoma with ectopic ending of Vater's ampulla. World J Gastroenterol 2009; 15(37): 4729-4731.

2. Yan JQ, Peng CH, Yang WP, Ding JZ, Zhou GW, Ma D, Li HW. Surgical management of benign duodenal tumours. ANZ J Surg 2010; 80 (7-8): 526-530.

3. Ramesh J, Council L, Wilcox CM. Recurrent pancreatitis caused by pancreatic ductal villous adenoma treated with endoscopic snare polypectomy. Endoscopy 2013; 45: E23-E24.

4. Sugita R, Furuta A, Ito K, Fujita N, Ichinohasama R,Takahashi S. Periampullary Tumors: High-Spatial-Resolution MR Imaging and Histopathologic Findings in Ampullary Region Specimens. Radiology 2004; 231:767-774.

5. Izgur V, Dass C, Solomides CC. Best cases from AFIP. Villous duodenal adenoma. AFIP archives. Radiographics 2010; 30:295-299.

6. Pham DT, Hura SA, Willmann JK, Nino-Murcia M, Brooke Jeffrey Jr R. Evaluation of Periampullary Pathology With CT Volumetric Oblique Coronal Reformations. AJR 2009; 193: 202-208.

7. Pourmand K, Itzkowitz SH. Small bowel neoplasms and polyps. Curr Gastroenterol Rep. 2016; 18:23-25.

8. Aslan S, Çetin B, Markoç F, Çetin A. A duodenal villous adenoma associated with in situ carcinoma: a case report. Turk J Cancer 2001;31:162-167.
9. McFarlane Me. Villous tumor of the duodenum: report of a case and review of the literature. J Hepatobiliary Pancreat Surg. 2001;8(1):107-9.

10. Chappuis CW, Divincenti FC, Cohn I Jr. Villous tumors of duodenum. Ann Surg 1989; 209:593-598.

11. Ring EJ, Ferrucci JT Jr, Eaton SB Jr, Clements JL. Villous adenomas of the duodenum. Radiology 1972; 104:45-48.

12. Chini $P$, Draganov PV. Diagnosis and management of ampullary adenoma: The expanding role of endoscopy. World | Gastrointest Endosc 2011 December 16; 3(12): 241-247.

13. Patel R, Varadarajulu S, Wilcox CM. Endoscopic ampullectomy: techniques and outcomes. J Clin Gastroenterol. 2012;46(1):8-15.

14. Azih LC, Broussard BL, Phadnis MA, Heslin MJ, Eloubeidi MA, Varadarajulu $S$, Arnoletti JP. Endoscopic ultrasound evaluation in the surgical treatment of duodenal and peri-ampullary adenomas. World J Gastroenterol. 2013; 19(4): 511-515.

15. Farah MC, Jafri SZ, Schwab RE, Mezwa DG, Francis IR, Noujaim S, Kim C. Duodenal neoplasm: role of CT. Radiology 1987;162:839-843.

16. Kazerooni EA, Quint LE, Francis IR. Duodenal neoplasm: predictive value of CT for determining malignancy and tumor respectability. AIR Am | Roentgenol 1992;159:303-309. 